\title{
UM ESTUDO SOBRE OS SIGNIFICADOS DE CONSUMO ASSOCIADOS AO CORPO FEMININO EM PEÇAS PUBLICITÁRIAS DE SUPLEMENTOS ALIMENTARES
}

\author{
João Felipe Rammelt Sauerbronn \\ joao.sauerbronn@fgv.br \\ Fundação Getulio Vargas - RJ / Brasil \\ Karla Andrea Dulce Tonini \\ karlatonini@hotmail.com \\ Universidade do Grande Rio - RJ / Brasil \\ Marluce Dantas de Freitas Lodi \\ marluce.lodi@gmail.com \\ Universidade do Grande Rio - RJ / Brasil
}

Recebido em 25/11/2010

Aprovado em 02/03/2011

Disponibilizado em 01/04/2011

Avaliado pelo sistema double blind review

Revista Eletrônica de Administração

Editor: Luís Felipe Nascimento

ISSN 1413-2311 (versão on-line)

Editada pela Escola de Administração da Universidade Federal do Rio Grande do Sul.

Periodicidade: Quadrimestral

Sistema requerido: Adobe Acrobat Reader.

\section{INTRODUÇÃO}

Estudos relacionados ao corpo e suas formas de manifestação na sociedade de consumo tem sido realizados por acadêmicos oriundos de diversas áreas do conhecimento. O corpo se transformou em ponto central de um mercado que cresce desde a segunda metade do século XX (Castro, 2004) e tem importância muito grande para área de marketing. No sentido pósmoderno, o corpo deixou de ter exclusivamente o papel conter um indivíduo e passou a compor um mercado, que lhe confere um valor (MEAMBER e VENKATESH, 1999). Adotando a perspectiva de Goldenberg e Ramos (2007), o corpo se transformou em capital e, como tal, passou a ser alvo de investimentos.

As relações entre o corpo e o consumo figuram entre as preocupações de diversos acadêmicos que vem estudando o papel do corpo na mídia (BERGER, 2007; GARRINI, 2007; SIQUEIRA e FARIA, 2007). O corpo feminino tem tido especial atenção de pesquisadores que tratam tanto de modificações corporais (PATTERSON e ELLIOT, 2003; REAd - Edição 68, Volume 17, Nº 1, jan/abr 2011 - p. 01-25 
Cunha, 2008), quanto da imagem da mulher em propagandas (ACEVEDO et al., 2006; NISHIDA, 2006).

O presente artigo busca analisar os significados atribuídos aos corpos femininos e transferidos através de peças publicitárias de suplementos alimentares. Mesmo não fazendo parte da lista de compras da maioria dos brasileiros, os suplementos alimentares têm seu consumo intensamente ligado ao corpo, ao processo de modificação deste e aos diversos rituais de consumo relacionados a esse processo. As peças publicitárias utilizadas para promoção desta categoria de produto utilizam imagens de corpos e apresentam textos que fazem alusão direta a ideais corporais e aos efeitos de seus componentes ao corpo.

Assim, a contribuição teórica desse artigo está localizada na proposta de uma discussão acerca da aproximação do mercado a dimensões humanas. Nesse processo de naturalização da presença do mercado, os corpos são definidos como posses e seus membros são transformados em peças de um produto que é colocado em um mercado. Espera-se que seja oferecida uma contribuição para uma teorização a respeito da "mercadização" das dimensões individual e corporal da vida.

Seguindo a proposta de Tavares (2006), as nove peças publicitárias coletadas foram analisadas com base no método de análise de discurso publicitário proposto por Pinto (2002). Assim, o significado do corpo feminino nas propagandas de suplementos alimentares foi compreendido com base na análise das funções de mostração (construção do universo do discurso), interação (estabelecimento de vínculos socioculturais com o interlocutor) e sedução (distribuição de afetos positivos ou negativos) (Pinto, 2002).

A estrutura do presente artigo é dividida em sete partes. Em sequiência à introdução, os autores buscam situar o leitor dentro da discussão acerca do que são suplementos alimentares e como estes produtos estão ligados ao corpo. A terceira seção apresenta a trajetória de transformação do significado do corpo para a sociedade e de sua incorporação pela propaganda. A quarta seção apresenta ao leitor a relação entre o uso corpo na publicidade e sua relação com o consumo. Em seguida, são apresentados os procedimentos metodológicos e o método de análise do discurso publicitário é tratado de forma mais profunda. A sexta seção traz as análises das peças e as propostas de categorias de propagandas baseadas nos significados atribuídos ao corpo feminino. Por fim, são apresentadas as considerações finais, que buscam propor uma contribuição para a compreensão a respeito das transferências de significados do corpo feminino através da publicidade.

REAd - Edição 68, Volume 17, No 1, jan/abr 2011 - p. 01-25 


\section{SUPLEMENTOS ALIMENTARES E O CORPO}

Os suplementos alimentares podem ser definidos como produtos feitos de vitaminas, minerais, produtos herbais, extratos de tecidos, proteínas e aminoácidos e outros produtos, consumidos com o objetivo de melhorar a saúde e prevenir doenças (CARVALHO e ORSANO, 2006). Segundo Carvalho e Orsano (2006), apesar da American Dietetic Association (ADA) afirmar que a melhor estratégia para promoção da saúde seja uma alimentação variada em nutrientes, e que a suplementação deve ser feita quando alimentação não garante o aporte de nutrientes de maneira segura, grande quantidade de suplementos são comercializados com a falsa promessa de fornecer energia, aumentar a performance atlética, o ganho de massa muscular, reduzir medidas, entre outros ganhos sem comprovação científica (CARVALHO e ORSANO, 2006).

As definições de suplementos são demasiadamente amplas e passíveis de confusão para o consumidor, pois geralmente suas funções são pouco esclarecedoras (CARVALHO e ORSANO, 2006). Segundo a Agência Nacional de Vigilância Sanitária (ANVISA) do Ministério da Saúde, os suplementos alimentares são classificados como alimentos para fins especiais através da Portaria n. 29 de 13 de janeiro de 1998, como alimentos para praticantes de educação física (Portaria n. 29 ANVISA, 1988).

Porém a Portaria n. 222 de 24 de março de 1998 trata especificamente dos alimentos para praticantes de educação física e os classificam como: repositores hidroeletrolítico para praticantes de educação física; repositores energéticos para atletas; alimentos protéicos para atletas; alimentos compensadores para praticantes de educação física; aminoácidos de cadeia ramificada para atletas e outros alimentos com fins específicos para praticantes de atividade física. A Portaria exclui os seguintes alimentos desta denominação: bebidas alcoólicas e gaseificadas; produtos que contenham farmacológicas estimulantes, hormônios e outras consideradas como doping pelo Comitê Olímpico Internacional (COI); produtos que contenham substâncias medicamentosas ou indicações terapêuticas; e produtos fitoterápicos e formulações à base de aminoácidos isolados, exceto os aminoácidos de cadeia ramificada e os aminoácidos essenciais utilizados em suplementação para alcançar o alto valor biológico preconizados pelas proteínas (Portaria n. 222 ANVISA, 1998).

Segundo Siqueira e Faria (2007): “os hábitos alimentares passam por uma mudança em que 'estilo de vida' está intrinsecamente associado a um cotidiano estressante, à falta de tempo e à busca por sossego, paz, saúde e tranqüilidade”. A maioria das pessoas que se alimentam de forma variada e saudável, não necessita de suplementos alimentares para 
alcançar suas necessidades energéticas, pois as adquirem diretamente da alimentação (CARVALHO e ORSANO, 2006).

Para Hirschburg, Fisberg e Mochizuki (2008), existe pressão da sociedade e da mídia em relação à busca de um corpo padrão, o que contribui para o aumento no uso de suplementos e anabolizantes. $\mathrm{O}$ atendimento nutricional em academias revela consumo indiscriminado (pouco documentado) de suplementos por praticantes de exercício. Além disso, percebe-se a resistência dos jovens às orientações sobre alimentação de profissionais nutricionistas, o que deixa os jovens mais propensos a ceder ao apelo do marketing e à pressão da mídia por um corpo esteticamente adequado ao padrão. Esta busca pela adequação estética no curto prazo torna os jovens vulneráveis à orientação de colegas e treinadores, quase sempre despreparados (HIRSCHBRUCH, FISBERG e MOCHIZUKI, 2008).

Também se pode dizer que atualmente as regras à exposição corporal são de ordem fundamentalmente estética. O autocontrole da aparência física é cada vez mais estimulado. Através do consumo de suplementos e de atividades físicas são prometidas, entre outras benesses, um abdômen cheio de gomos salientes ou nádegas duras livres de celulites caso o indivíduo se dedique a tal propósito e receba todas as informações fornecidas como um conjunto de obrigações (GOLDENBERG e RAMOS, 2007). Desta forma, cada indivíduo é responsável pelo cuidado e manutenção do seu corpo e pelo retardamento do envelhecimento. Esta mensagem passa a ser incorporada às propagandas de produtos relacionados ao corpo, tratando da boa aparência corporal como uma virtude e como expressão externa de sucesso (GOLDENBERG, 2007).

\section{TRANSFORMAÇÃO DO SIGNIFICADO DO CORPO E SEU USO NA PROPAGANDA}

Na década de 20, as propagandas utilizando o corpo, representavam à relação saúdedoença. Nessa concepção, beleza significava corpo sem doença, ser saudável era apresentar um corpo robusto, corado e gordo, o que se prometia como benefício de cosméticos e medicamentos era a cura. Trata-se do início de uma transição nos cuidados com o corpo, a doença tornou-se objeto de investigação e, na medida em que se tornou conhecida, permitiu que o olhar da ciência se desviasse para a estética do corpo (HOFF, 2005).

No final da década de 20 , mulheres sob influência das indústrias de cosméticos, da moda, da publicidade e do cinema incorporaram o uso da maquiagem, principalmente o batom, em suas rotinas e passam a valorizar o corpo esbelto e esguio. A combinação dessas

REAd - Edição 68, Volume 17, Nº 1, jan/abr 2011 - p. 01-25 
quatro indústrias foi fundamental para a vitória do corpo magro sobre o gordo, no decorrer do século XX. Com base nas reflexões de Anthony Giddens, Castro (2004) reforça que a década de 20 representa um marco histórico do surgimento ideal de magreza. Neste sentido, o indivíduo adota a responsabilidade de modelar seu próprio corpo, como forma de definir sua identidade e o projeto do self.

A partir da segunda metade dos anos 50, configurou-se a revolução de veraneio, que impôs um novo conceito de férias de verão, em que a exposição do corpo ocupa espaço central. A expansão publicitária foi responsável pela difusão de hábitos relativos aos cuidados com o corpo e às práticas de higiene, beleza e esportivas, preconizadas por médicos e moralistas burgueses desde o início do século. As imagens de estrelas de cinema com sorriso branco e cabelos brilhantes vendendo creme dental e xampu anunciavam novas práticas, difundiam uma nova maneira de lidar com o corpo e um novo conceito de higiene (Castro, 2004). Nos anos 50, revistas voltadas para o público feminino, traziam atrizes do cinema europeu e norte-americano, vencedoras de concurso de miss ou de beleza para aconselhar outras mulheres sobre os cuidados com a beleza (SIQUEIRA e FARIA, 2007).

Segundo Castro (2004), a preocupação com o corpo se intensificou na segunda metade do século XX, e foi crucial na formulação de um novo ideal físico fortemente construído pela indústria cinematográfica. A partir daí, o culto ao corpo ganhou uma dimensão social inédita: Industrialização e mercantilização, difusão generalizada das normas e imagens, profissionalização do ideal estético com a abertura de novas carreiras, o aumento dos cuidados com o rosto e com o corpo fizeram nascer à idéia de um novo momento da história da beleza feminina e, em menor grau, masculina. A mídia adquiriu um imenso poder de influência sobre os indivíduos, generalizou a paixão sobre a moda, expandiu o consumo de produtos de beleza e tornou a aparência uma dimensão essencial da identidade para um maior número de mulheres e homens (GOLDENBERG, 2007).

Nos anos 60, houve o surgimento da pílula anticoncepcional e da chamada revolução sexual e do movimento feminista. O corpo entrou em cena como lócus da transgressão, do delírio e do transe, pelas experiências da droga e do sexo (CASTRO, 2004). Observa-se também nesse período, no que tange as propagandas em revistas femininas a imagem da mulher seminua, tocando o próprio corpo sugerindo prazer. Surgiu o discurso de que era preciso conhecer, explorar e tocar o próprio corpo para torná-lo mais autêntico e natural (SIQUEIRA e FARIA, 2007).

REAd - Edição 68, Volume 17, No 1, jan/abr 2011 - p. 01-25 
Nos anos 80, o corpo ganhou vulto nunca antes alcançado, em termos de visibilidade e espaço na vida social. As práticas físicas passaram a ser mais regulares e freqüentes (CASTRO, 2004). Com o crescimento do 'mercado do músculo' nos anos 80 e do consumo de bens e serviços destinados à manutenção do corpo, impérios industriais com atividades diversificadas ocuparam essa fatia de mercado. Essas corporações passaram a produzir tanto aparelhos de musculação quanto suplementos nutricionais, ou ainda publicar revistas especializadas sobre boa forma, saúde, regimes alimentares e desenvolvimento corporal (SIQUEIRA e FARIA, 2007).

Nos anos 90, teve início uma inversão do significado do corpo 'natural', o avanço da medicina e o desenvolvimento tecnológico possibilitaram modificar o corpo através de intervenções cirúrgicas com finalidade estética alternando assim o status corporal. Passou a se observar a impossibilidade de aceitação do corpo natural como ele se apresenta. A partir de um corpo modelo - perfeito - passaram a ser indicadas as várias intervenções plásticas, próteses de silicone, lipoaspiração, cirurgias de abdômen, dentre outras. Passou a não haver mais parte do corpo que escapasse às possibilidades de modificação (HOFF, 2005).

Para Malysse (2007), ao modificar a forma do corpo, o indivíduo tenta controlar tudo aquilo que foge ao seu controle na vida social, construindo assim, um modelo que o personifique e com o qual se identifique. Atualmente, observa-se uma tendência de promover modificações no corpo desde interferências sutis, obtidas em longo prazo com a utilização de cosméticos e da prática de ginástica, até alterações corporais mais permanentes, como o bodybuilding, a tatuagem e o uso de piercing. Nesse aspecto, modificar o corpo consiste num imperativo de autodeterminação e de vontade, a desvalorização do corpo 'natural' fundamenta a necessidade de modificação e reconstrução do corpo (HOFF, 2005).

Malysse (2007), em seu estudo sobre a corpolatria, percebeu que a visão do corpo do outro influenciava a percepção que cada indivíduo tinha do seu próprio corpo, e que, por meio de mimese social, o visual tornava-se social. Assim, há uma construção cultural do corpo, com uma valorização de certos atributos e comportamentos em detrimentos de outros, fazendo com que haja um corpo típico para cada sociedade. Esse corpo, que pode variar de acordo com o contexto histórico e cultural e é adquirido pelos membros da sociedade por meio da imitação prestigiosa (GOLDENBERG, 2007). Sendo assim, o corpo se torna também capital, cercado de enormes investimentos (tempo, dinheiro, entre outros). O corpo "em forma" apresenta-se como sucesso pessoal (GOLDENBERG e RAMOS, 2007). No Brasil, as 
mulheres imitáveis são as modelos, atrizes, cantoras e apresentadoras de televisão, todas fazendo uso do seu corpo como capital.

Para Goldenberg (2007) é interessante destacar a ambigüidade que o culto ao corpo gera principalmente na cultura de classe média. Quanto mais se impõe o ideal de autonomia individual, mais aumenta a exigência de conformidade aos modelos sociais do corpo. A obsessão com a magreza, a multiplicação das dietas, das atividades do corpo e o aumento das intervenções cirúrgicas testemunham o poder normalizador dos modelos, um desejo maior de conformidade estética que se choca com o ideal individualista e sua exigência de individualização dos sujeitos (GOLDENBERG, 2007).

Em um contexto social e histórico particularmente instável e mutante, onde a forma tradicional de produção de identidade - a família, a religião, a política, o trabalho entre outros - encontram-se enfraquecidos, pode-se imaginar que muitos indivíduos e grupos estejam usando seu próprio corpo como um meio de expressão (ou representação) do eu (GOLDENBERG e RAMOS, 2007). Dessa forma, não é surpreendente que a propaganda utilize o corpo como forma de construir um discurso publicitário.

\section{O USO DO CORPO NA PUBLICIDADE E SUA RELAÇÃO COM O CONSUMO}

A publicidade tem por objetivo estabelecer um diálogo entre os acontecimentos do presente e as tendências em relação a comportamentos, expectativas, desejos e percepções dos consumidores, construindo assim, um discurso que se materializa através das representações da mídia (HOFF, 2005).

Segundo McCracken (2003), a publicidade atua na transferência do significado, associando um bem de consumo a uma representação do mundo culturalmente constituído dentro da modelagem de um anúncio específico. Quando esta relação simbólica é estabelecida com sucesso, o espectador atribui ao bem de consumo propriedades que existem no mundo culturalmente definido. Essa conexão entre as propriedades culturais construídas e as desconhecidas do bem de consumo é que se chama transferência de significado. O sucesso dessa relação simbólica é obtido através de escolhas estabelecidas pela rede de categorias e princípios culturais da sociedade, que devem retratar exatamente a cultura estabelecida, dessa forma, o sistema de consumo supre os indivíduos com materiais culturais necessários a sua auto-realização.

O corpo da publicidade materializado e difundido em diversas linguagens, expressa os significados de uma cultura, pois as representações criadas para o corpo descrevem os REAd - Edição 68, Volume 17, No 1, jan/abr 2011 - p. 01-25 
indivíduos que compõem a sociedade como são ou gostariam de ser. Para a mídia, o corpo é um instrumento utilizado para dar relevância ao produto, e desta relação nasce o que se chama de corpo-mídia. Significa ser um corpo presente nos textos midiáticos de natureza virtual, uma imagem idealizada, atribuída de valores culturais. O corpo-mídia apresenta-se sem as imperfeições do corpo 'natural' despertando assim o consumo do corpo perfeito (HOFF, 2005). O corpo 'virtual' apresentado pela mídia é um corpo de mentira, medido, calculado e artificialmente preparado o que se torna uma poderosa mensagem de corpolatria. Nesse caso, os indivíduos, principalmente as mulheres, são convidados a considerar defeitos em seu corpo, e mesmo gozando de saúde, consideram que seus corpos não são perfeitos e precisam ser corrigidos (MALYSSE, 2007).

Goldenberg e Ramos (2007) associam o corpo a 'objeto de consumo', pois a publicidade antes exaltava as vantagens de um produto, e atualmente produz o consumo como estilo de vida, procriando um produto próprio: o consumidor, intranqüilo e insatisfeito com sua aparência.

No Brasil, e mais particularmente no Rio de Janeiro, o corpo cuidado, sem marcas indesejáveis e sem excessos, passa a ser muito mais valorizado do que a própria roupa (GOLDENBERG e RAMOS, 2007). Segundo Castro (2004), o consumo relacionado com o culto ao corpo está em evidência.

Segundo Cunha (2008), esses investimentos relacionados ao corpo podem ser entendidos como forma de consumo, ou seja, são comportamentos que se adquire, para transformar o corpo, tal como se adquirem roupas ou serviços de estética. Dessa forma, consumir, em geral, é uma forma importante para o desenvolvimento e para a afirmação da identidade. Nesse caso, o consumo envolve várias atividades, atores e um conjunto de bens e serviços que não se restringem necessariamente a forma de mercadorias (BARBOSA e CAMPBELL, 2007). Os bens de consumo possuem significado cultural além de sua utilidade e valor comercial e é através dos bens que as categorias culturais são valorizadas.

Os bens são uma oportunidade para fazer cultura material, eles permitem a distinção pública, visual, das categorias culturalmente especificadas. Assim, o significado consiste nas idéias ou nos valores de acordo com a organização, avaliação e construção dos fenômenos culturais, facilitando assim, sua classificação e inter-relação com os bens e a vida social. (MCCRACKEN, 2003). A verdadeira necessidade suprida pelo consumo diz respeito à construção de significados e categorias culturais. O consumo do significado simbólico confere 
ao indivíduo a oportunidade de construir, manter e comunicar a sua identidade e os seus significados sociais (SAUERBRONN, AYROSA e BARROS, 2009).

O significado dos bens passa para um mundo culturalmente constituído, ou seja, pela experiência cotidiana carreada de suas crenças e pressupostos de sua cultura e se transfere para o bem de consumo com a ajuda de produtores, publicitários e consumidores (MCCRACKEN, 2003, p.101). No caso do corpo, a aparência e a apresentação do corpo tornam-se centrais na construção da auto-identidade através da consciência do corpo, e da sua aproximação das imagens ideais para aumentar seu valor, em termos negociáveis. A questão do consumo torna-se fundamental para a construção da imagem corporal (CUNHA, 2008).

Segundo McCracken (2003, p. 100), existem três localizações para o significado: o mundo culturalmente constituído, o bem de consumo e o consumidor individual, bem como dois momentos de transferência: mundo-para-bem e bem-para-indivíduo. Uma melhor compreensão do movimento do significado cultural e de consumo pode ajudar a esclarecer parte da complexidade do consumo atual em relação ao corpo e sua participação na sociedade de consumo.

Segundo Douglas e Isherwood (2009), existem dificuldades para fixação e estabilidade dos significados, isto pode ser amenizado com a criação de rituais, ou seja, convenções que constituem definições públicas. Os rituais tanto nas sociedades tribais como nas contemporâneas serviriam para explicitar os significados. Os rituais seriam, então, uma oportunidade para ensinar e aprender, trocar informações, classificar e discriminar os significados (ALMEIDA e ROCHA, 2008). Nessa perspectiva, os bens são acessórios rituais e o consumo é um processo ritual cujo objetivo é dar sentido ao fluxo incompleto dos acontecimentos (DOUGLAS e ISHERWOOD, 2009, p. 112).

Para McCraken (2003), a transferência do significado dos bens de consumo para o consumidor é feita através de uma ação simbólica, ou ritual, como ferramenta para a manipulação do significado cultural. É uma forma de afirmar, evocar, assinalar ou revisar os símbolos e significados convencionais estabelecidos culturalmente, a partir de quatro propósitos: troca, posse, arrumação e despojamento. Sendo assim, o entendimento desses rituais de consumo, ampliou a fundamentação da análise o discurso publicitário nas propagandas que foram analisadas nesse estudo.

McCracken (2003) afirma que o ritual de troca é um potente meio de influência interpessoal, permite insinuações sobre certas propriedades simbólicas na vida de um receptor-de-presentes, iniciando uma transferência de significado do doador-de-presentes para

REAd - Edição 68, Volume 17, No 1, jan/abr 2011 - p. 01-25 
o receptor. Significa que o doador tenta influenciar o receptor com as propriedades simbólicas do presente, ou seja, propriedades que ele gostaria que o receptor absorvesse (ALMEIDA e ROCHA, 2008).

Segundo Malysse (2007), a busca da forma ideal condiciona o desenvolvimento de uma variedade de artigos destinados ao corpo, como suplementos alimentares, tratamentos estéticos, intervenções cirúrgicas entre outros, isso faz com que haja a troca de bens em função do seu significado e das suas promessas de resultado a curto prazo. No caso do consumo através do corpo, o doador e receptor de presentes são a mesma pessoa, pois se trata de um investimento pessoal (CUNHA, 2008).

Já o ritual de posse, permite ao consumidor transferir o significado dos bens para suas vidas. Existem rituais de posse dedicados a personalizar o objeto, ou seja, uma tentativa de transferir significado do próprio mundo do indivíduo para o recém-adquirido, fazendo com que os indivíduos criem um mundo de bens pessoal. $\mathrm{O}$ significado que a personalização transfere para o bem é o significado coletivo associado à experiência individual. Já a publicidade transfere para os bens o significado da coletividade.

A busca pelo corpo perfeito faz com que o indivíduo busque a adesão de modelos de beleza padronizados (BERGER, 2007). Desta forma, o indivíduo entende o seu corpo como objeto externo e se dedica à personalização deste através da transferência de significado do mundo culturalmente construído pela mídia.

O ritual de arrumação, parte da extração do significado simbólico dos bens perecíveis, e seu investimento no consumidor. A finalidade deste ritual é assegurar que as propriedades especiais e perecíveis que residem em um bem possam viver no consumidor individual. Por exemplo, a linguagem estabelecida para descrever algumas maquiagens, produtos para modelar cabelo, e roupas fornece um conhecimento tácito das propriedades que podem ser obtidas desses bens através dos rituais de arrumação específicos, o mesmo podemos relacionar sobre o uso de suplementos alimentares e seus efeitos no corpo (MCCRACKEN, 2003).

Alguns indivíduos adotam os significados dos bens em termos pessoais. Essa possível confusão estimula o recurso do ritual de despojamento, que ocorre quando o bem deixa de ter significado para o indivíduo, é rejeitado e substituído. Em relação ao consumo do corpo, Berger (2007), nos diz que o corpo pode servir como substrato da identidade, mas, a busca pelo corpo perfeito pode levar a desconstrução desta identidade através do consumo de 
cirurgias plásticas, e outros produtos utilizados com o objetivo de atingir a supremacia corporal.

Portanto, o modelo de transferência de significado através da publicidade para o bem de consumo proposto por McCracken (2003) também pode oferecer suporte à proposta de analisar o uso do corpo feminino nas ações de comunicação dos fabricantes de suplementos nutricionais. $\mathrm{O}$ uso de imagens visuais e material verbal relacionam o mundo e o objeto de maneira particular, o material verbal torna explícito o que está implícito na imagem, facilitando assim a transferência do significado para o bem de consumo. A propaganda é o canal que movimenta constantemente essa transferência de significado. Uma compreensão da transferência do significado cultural e de consumo pode ajudar detalhar o que é ser uma sociedade de consumo (MCCRACKEN, 2003).

\section{PROCEDIMENTOS METODOLÓGICOS}

Frente à proposta de analisar os significados atribuídos ao corpo feminino em peças publicitárias de suplementos alimentares, foi necessário desenvolver uma proposta metodológica capaz de alcançar este objetivo. Mesmo estando claro que o trabalho seria eminentemente interpretativo e baseado na visão construída pelos pesquisadores, foi necessário encontrar uma ferramenta que permitisse acessar o discurso publicitário.

Segundo Carvalho (1996), o discurso publicitário é um dos instrumentos de controle social utilizando a linguagem da sedução com o objetivo de produzir o consumo. Sendo assim, um anúncio não se limita apenas em mostrar o produto, é também forma de representação social e permite a exploração dos códigos verbais e não verbais expostos nas propagandas. O discurso publicitário usa recursos estilísticos e argumentativos da linguagem cotidiana, essa própria voltada para informar e manipular (TAVARES, 2006). Para Carvalho (1996), o discurso publicitário utiliza linguagem da sedução com o objetivo de produzir o consumo. Através do que é mostrado em propagandas são construídas práticas sociais e culturais, ficando denotada uma forma de dominação simbólica (NISHIDA, 2006).

De acordo com Tavares (2006), a mensagem publicitária é constituída de linguagem verbal e outros sistemas semióticos (como as imagens), o que torna necessário o uso de uma ferramenta metodológica específica, desenvolvida na área de comunicação. A proposta de Pinto (2002) para a análise do discurso publicitário pareceu ser adequada para fazer com que os pesquisadores acessassem o discurso publicitário de forma mais consistente. De forma a 
possibilitar uma operação mais objetiva do método, Pinto (2002) propõe a análise do discurso publicitário a partir de três funções: mostração, interação e sedução.

A função de mostração constrói o referente ou universo de discurso do qual o texto fala e acontece nos momentos em que aparecem os sujeitos principais das propagandas, as relações entre o produto e, no caso deste trabalho, o corpo feminino. Constrói-se um universo que faz referência com o texto, onde emissor e receptor vivem. Nesse universo é criado um vínculo, a partir do uso de linguagem e símbolos que mostram ou recriam um determinado universo em questão. A função mostração "consiste em designar e descrever as coisas ou pessoas em que se fala, estabelecendo relações entre elas no tempo e no espaço" (PINTO, 2002, p.65).

A função interação estabelece vínculos socioculturais necessários para dirigir a propaganda ao seu interlocutor (PINTO, 2002). Nessa função são observadas as relações de poder existentes nos discursos usados. A interação consiste em interpelar e estabelecer relações de poder com o receptor na tentativa de cooptá-lo e de agir sobre ele ou sobre o mundo por seu intermédio (PINTO, 2002, p.67). Para que as hierarquias sociais reconhecidas a partir do processo de comunicação sejam reproduzidas, essas são reforçadas através de frases assertivas, imperativas, interrogativas, geralmente desfiguradas do texto e apresentadas em tópicos.

A função sedução distribui os afetos positivos ou negativos cuja hegemonia reconhece e/ou quer ver reconhecida (PINTO, 2002). Nessa função foi observado como são demonstrados os valores positivos e negativos no uso da imagem do corpo feminino. A emoção é atingida através de diversas formas de manipulação de imagens e de palavras que visam alcançar a desvinculação da realidade do receptor para que este se veja em uma situação fora de sua realidade (PINTO, 2002, p.65). Assim, as pessoas, coisas e acontecimentos referidos são marcados com valores positivos (eufóricos) ou negativos (disfóricos) que geram reações afetivas favoráveis ou desfavoráveis (PINTO, 2002, p. 68).

O corpus de dados foi composto por formas de publicidade que alcançam os usuários de suplementos alimentares. Dessa forma, foram utilizados cinco folders promocionais, distribuídos em lojas de produtos naturais (locais de aquisição do produto) e quatro propagandas publicadas em revistas especializadas ('Suplementação' e 'Muscle in Form' revistas que são utilizadas como fonte de informação por consumidores de suplementos alimentares). A escolha das peças promocionais foi baseada na disponibilidade de peças promocionais nos pontos de venda e nas revistas impressas utilizadas como fonte de 
informação dos consumidores de suplementos alimentares. Assim, foram utilizadas todas as peças promocionais disponíveis para consumidores de suplementos alimentares no município do Rio de Janeiro ao longo do segundo semestre de 2009. Tanto os folders quanto as propagandas de revistas especializadas foram selecionados com base em dois critérios: tratarem de suplementos alimentares e mostrarem de alguma forma o corpo feminino.

As peças foram numeradas de 01 a 09 e distribuídas entre três pesquisadores: duas mestrandas em administração, uma nutróloga e outra bacharel em marketing, e um doutor em administração com formação em economia. Dessa forma, cada um dos pesquisadores pode realizar uma primeira rodada individual de análise das propagandas buscando identificar as funções de mostração, interação e sedução dos anúncios, conforme sugerido por Pinto (2002). De forma complementar, foram analisados os rituais de troca, posse, arrumação e despojamento propostos por McCracken (2003) representados nas peças publicitárias. A intenção foi explorar ao máximo a capacidade de interpretação dos pesquisadores dentro destas perspectivas. Em uma segunda rodada, a análise de cada peça foi discutida conjuntamente pelos pesquisadores. Foram discutidas as visões de cada um dos pesquisadores e, como resultado das discussões, foi construída a análise da peças apresentada na seção seguinte.

Por se tratar de um trabalho de orientação interpretativa, não havia uma proposta de categorização definida previamente à análise das peças publicitárias, tampouco havia um limite previamente determinado do número de categorias a serem construídas. A partir da análise das funções de mostração, interação e sedução as peças foram interpretadas e essa interpretação gerou as categorias que são apresentadas a seguir. Trechos de textos presentes nas peças são utilizados na análise e as peças são reproduzidas em anexo ao texto. Devido às limitações de espaço e tamanho de arquivo as imagens foram reproduzidas com baixa definição em anexo ao artigo.

\section{ANÁLISE DAS PEÇAS}

Conforme esperado pelos pesquisadores, alguns componentes do discurso publicitário foram comuns a todas as peças publicitárias e manifestaram funções de interação semelhantes. A redução de gordura é um tema constantemente abordado e pareceu estar relacionado a uma espécie de ritual de despojamento: o abandono do corpo redondo, gordo e flácido. Não foram encontradas imagens que tratassem diretamente dessa manifestação de ritual de despojamento, como pode ser visto em propagandas que utilizam fotos de corpos que mostram a REAd - Edição 68, Volume 17, No 1, jan/abr 2011 - p. 01-25 
transformação (os tradicionais 'antes e depois'). Os textos das peças utilizadas, entretanto, abordam de forma direta esta questão - "faz bem para a sua pele" (peça 04); "Tecnologia contra os quilinhos irritantes" (peça 08). Algumas peças utilizam o suporte científico, que denota através da função interação a justificativa para consumo a partir de argumentos científicos - "Segundo um importante estudo conduzido por Jean Michel Gaulier e colaboradores 'o óleo de Cártamo pode diminuir a gordura corporal e pode contribuir para a redução da massa corporal gorda e o peso a longo prazo"” (peça 01).

Também sem causar surpresas aos pesquisadores, as propagandas encontradas tratam de forma explícita o corpo como algo que se possui. Assim, as peças promocionais apresentam de forma explícita rituais de posse de corpos firmes, magros, sem flacidez ou qualquer irregularidade. Este ritual de posse faz sentido no momento em que o corpo passa a ser o objeto a ser consumido e o suplemento alimentar passa a ser o meio para consumo desse corpo que atende a um padrão e para a possibilidade de alteração do próprio corpo. O corpo feminino se produtifica, conforme apontado por Lipovetsky (2000). Ao se transformar em produto, passa a poder/dever ser modificado/adequado para ter valor. O discurso das propagandas de suplementos oferece o caminho para a valorização do corpo como objeto.

Afora os aspectos comuns observados, as peças apresentaram algumas características que permitiram a categorização. De acordo com os discursos publicitários utilizados, foi possível separar quatro categorias de peças publicitárias.

\subsection{Categoria 01 - Corpo como Fonte de Poder}

A primeira categoria (constituída pelas peças 01, 05 e 09) mostra o corpo como fonte de poder da mulher. As três peças que compõem esta categoria utilizam a função de mostração para construir um universo centrado no corpo feminino. O corpo feminino é mostrado quase inteiramente (da altura da canela para cima, mais precisamente), sem destaque para alguma parte específica. As mulheres utilizam pouca roupa e seus cabelos estão à mostra (mesmo que presos, caem de forma expressiva sobre os ombros na peça 05), são lisos, compridos e claros e complementam a proposta de um corpo belo a ser consumido.

Na peça 01, a mulher retratada está no primeiro lugar de uma fila composta por outras mulheres, cujos corpos não podem ser vistos com clareza. Na peça 05, a mulher é fotografada em seu momento de treinamento em uma academia de ginástica. Na peça 09, a mulher, uma atleta patrocinada pela marca de suplementos alimentares, apresenta seu corpo em uma pose 
que remete a concursos de beleza. $\mathrm{O}$ corpo se torna um objeto que permite à mulher alcançar resultados, chegar à frente, ser vitoriosa, ser valorizada.

O produto também compõe a função de mostração, está claramente à mostra, mas não domina a cena. Entretanto, mesmo estando em posição secundária em relação ao corpo, o produto faz parte de seu universo de consumo: o produto dá suporte ao corpo e lhe dá condições de ser poderoso, feminino e valorizado.

As peças centradas no corpo como fonte de poder, constroem interação a partir de texto: "Absolutamente maravilhosa" ou "absolutamente incontestável" (peça 01); ou "Para você que quer resultado" (peças 05 e 09); e de imagens de corpos femininos fortes, magros e femininos. A relação de poder estabelecida com o receptor da mensagem é de transformação do visual em social, conforme proposto por Malysse (2007). O status de ter um corpo feminino perfeito é construído socialmente: a primeira posição na fila (peça 01) impõe o discurso de vencedora através do corpo. A atividade física em local público (academia) reforça os aspectos socioculturais utilizados nos discursos das peças.

A sedução está localizada nos rostos das mulheres retratadas nas peças que mostram sentimentos de orgulho e satisfação das mulheres com seus corpos, além da obstinação em perseguir o corpo perfeito, que é alcançável. Outro sentimento observado é a auto-estima, reforçada pelos textos e pelo ritual de posse de um corpo perfeito. Estes afetos positivos trazem ao receptor uma perspectiva positiva de sucesso e de valor para o outro.

\section{Figura 01 - Corpo como Fonte de Poder}

\begin{tabular}{|l|l|}
\hline Função de Mostração & Corpo Poderoso - corpo é um objeto que gera valor para a mulher \\
\hline Função de Interação & Status do Corpo - corpo perfeito construído socialmente \\
\hline Função de Sedução & Auto-Estima Elevada - afetos positivos: orgulho, obstinação \\
\hline
\end{tabular}

Fonte: elaborado pelos autores

\subsection{Categoria 02 - Corpo como Local de Ação do Produto}

As peças 02,04 e 07 trazem o produto como protagonista. $\mathrm{O}$ corpo assume uma posição secundária que se resume a demonstrar a ação do produto. Desta forma não são mostrados rostos, filas, interações com outras pessoas, locais de prática de exercícios, campeãs ou atletas. As peças mostram apenas a embalagem do produto e a parte do corpo onde a ação do produto supostamente se dá de forma mais potente.

Na peça 02, a barriga e a perna de uma mulher são mostradas em fundo negro, compondo a embalagem do produto, reproduzida na peça. Na própria embalagem a função REAd - Edição 68, Volume 17, No 1, jan/abr 2011 - p. 01-25 
UM ESTUDO SOBRE OS SIGNIFICADOS DE CONSUMO ASSOCIADOS AO 16

CORPO FEMININO EM PEÇAS PUBLICITÁRIAS DE SUPLEMENTOS

ALIMENTARES

interação é construída com base em texto: "Potencializador - Linolen AGE"; "Metabolismo ativado $24 \mathrm{~h}$ " e "Oxidação de gorduras". O texto é técnico, mas constrói uma relação com o receptor que promove a idéia de ação eficiente do produto através de expressões como "potencializador", "ativado 24h", “oxidação de gorduras". Somando o texto ao fragmento de corpo mostrado, o discurso proposto é da ação do produto sobre o corpo, de forma clara e objetiva.

A peça 04 utiliza a imagem de um fragmento de corpo molhado (mostra a barriga e parte do seio) sobre o fundo negro. $\mathrm{O}$ fato do corpo mostrado estar molhado pode sugerir a prática de exercícios, mas como não é vista nenhuma peça de roupa e o corpo aparenta estar nu, o receptor é levado a pensar em uma situação de exposição íntima do corpo, durante o banho ou durante o sexo.

O texto "Colágeno faz bem para sua pele" e "Colagen Plus atua na sustentação intercelular da pele e é responsável por sua firmeza e elasticidade" apresenta de forma explícita a ação do produto sobre o corpo. A interação é construída de forma direta e intensa.

A peça 07 repete o padrão de exibir fragmento do corpo sobre fundo escuro, mas contém algumas alterações que são dignas de nota. Trata-se de um produto específico para as mulheres que constrói o universo de significado em torno da ação sobre o corpo feminino. $\mathrm{O}$ local específico de atuação do produto no corpo está restrito à barriga, onde se lê o texto "rico em fibras", referindo-se claramente aos recorrentes casos femininos de constipação. A interação é reforçada pelo restante do texto, que inclui: "fórmula especial para atender às necessidades femininas" e "... alternativa natural aos problemas decorrentes da menopausa...".

A embalagem do produto é reproduzida na peça e mostra um corpo feminino forte, magro, usando salto alto, mas sem a cabeça. Esta divisão entre corpo/rosto e cabeça também ajuda a construir a idéia de aproximação à mulher. Afinal, fica a cargo da mulher (receptor) ingerir o produto e dar um rosto àquele corpo apresentado. $\mathrm{O}$ consumo do produto permite ao consumidor acesso ao corpo/objeto.

Nesta categoria de peças publicitárias, a função de sedução é construída com base na sensualidade das curvas dos corpos apresentadas. Mesmo sem mostrar o corpo inteiro em nenhum dos casos, as peças que compõem esta categoria apresentam ênfase elevada nas curvas femininas. A curva formada pela perna e pela barriga do corpo feminino apresentado na peça 02 , a curva do seio mostrada na peça 04 e a curva da cintura apresentada na peça 07 enfatizam as partes e a busca pela perfeição em detalhes.

REAd - Edição 68, Volume 17, Nº 1, jan/abr 2011 - p. 01-25 
O ritual de posse se dá em partes: o consumo da pele firme, da barriga lisa, do seio firme. Ao fragmentar o corpo, divide-o em peças e reforça a idéia de ação do produto sobre este. O piercing utilizado na peça 04 chama a atenção para a barriga e reforça a possibilidade de modificação do corpo (causada pelo produto).

\section{Figura 02 - Corpo como Local de Ação do Produto}

\begin{tabular}{|l|l|}
\hline Função de Mostração & $\begin{array}{l}\text { Ação do Produto - corpo é um local onde produto exprime seu valor, } \\
\text { corpo em partes, piercing reforça a idéia de modificação corporal. }\end{array}$ \\
\hline Função de Interação & Baseada em Técnica - potência, aceleração, sustentação, rico em fibras. \\
\hline Função de Sedução & Sensualidade - curvas, corpo molhado, feminilidade \\
\hline
\end{tabular}

Fonte: elaborado pelos autores

\subsection{Categoria 03 - Corpo como Confirmação do Produto}

Nesta categoria, assim como na categoria 02 , o produto está no centro do foco e os seus efeitos são destacados. Entretanto, há diferenças nas formas com as quais as funções do discurso são apresentadas, tanto em relação à categoria 02 quanto à categoria 01 . $\mathrm{O}$ corpo não centraliza a expressão de valor, tampouco é mostrado apenas como o local onde o produto age, mas serve como confirmação do produto. O corpo não domina o discurso, mas é o argumento que surge vigorosamente em favor do produto.

A função de mostração é construída de forma compartilhada pela mulher e pelo produto. Não são focadas partes, mas o corpo inteiro da mulher, incluindo rosto e cabelos. Para não rivalizar com o produto do ponto de vista de construção imagética, entretanto, os cabelos são escuros e procuram confirmar a expressão facial que oferece olhares imperativos, diretos ao receptor, construindo a função interação em conjunto com a autoridade gestual. A função sedução é construída a partir de argumentos baseados em diminuição de esforço e aumento do prazer em utilizar os produtos e são reforçados pelas expressões faciais e corporais das mulheres retratadas.

A peça 03 apela explicitamente para um argumento imposto e suportado pelo texto explicativo de cada um dos produtos - "Não invente. Tome Bioslim"; "Desenvolvido especialmente para pessoas que buscam um estilo de vida moderno e saudável”. A variedade de produtos da linha é mostrada e os lançamentos evidenciados. A função mostração é complementada pela imagem de uma mulher trajando vestido decotado, pressionado na região da barriga para evidenciar efeitos do produto no corpo.

REAd - Edição 68, Volume 17, No 1, jan/abr 2011 - p. 01-25 
Os argumentos da peça são reforçados pela autoridade gestual do dedo em riste e pelo olhar imperativo que constroem a interação com o receptor. O receptor recebe uma ordem para consumir o produto. O corpo é apresentado como base para o consumo e, portanto, objeto que surge como resultado do consumo.

A função sedução é construída a partir da idéia de que o consumo de suplementos alimentares pode ser prazeroso (saboroso) - “...uma bebida saborosa e perfeita para todos os momentos do dia" - e prático - "mantém todos os princípios ativos da planta com a praticidade do preparo instantâneo." Dessa forma, parece não ser muito difícil ou penoso conquistar o corpo da modelo mostrado na propaganda.

A peça 08 coloca em evidência o texto: "tecnologia contra os quilinhos irritantes". A imagem da mulher que dá suporte ao produto mostra um corpo magro, vestido por uma camiseta curta e uma calcinha e com círculos que marcam no corpo os efeitos do produto. A função de mostração coloca a mulher e seu corpo como confirmadores do produto.

A função de interação fica mais evidente no texto: "ninguém precisa mais sofrer para se ver livre daqueles quilinhos que parecem resistir a qualquer esforço." O olhar imperativo oferece cumplicidade ao receptor. A mulher domina com o olhar, mas aponta a atuação do produto em seu corpo, gerando interação a partir da imagem. Ao mesmo tempo em que gera cumplicidade, também promove afetos no receptor. A função de sedução é baseada na praticidade e na diminuição de esforço.

Figura 03 - Corpo como Confirmação do Produto

\begin{tabular}{|l|l|}
\hline Função de Mostração & Aval do corpo - confirmação da ação do produto pela mulher \\
\hline Função de Interação & Autoridade gestual, Olhar imperativo \\
\hline Função de Sedução & Prazer e Praticidade - sabor, praticidade, modernidade \\
\hline
\end{tabular}

Fonte: elaborado pelos autores

\subsection{Categoria 04 - Corpo Feminino Comportado}

Esta categoria, constituída apenas da peça 06, apresenta características de discurso muito particulares. O corpo feminino é apresentado em segundo plano, junto a um homem cujo corpo está mais a mostra do que o da mulher. A mulher não controla a cena e seu corpo não é fonte de poder. O corpo da mulher dá suporte ao domínio masculino que a acolhe e controla. A mulher tem seu olhar direcionado para a máquina fotográfica que é controlada pelo homem, suas curvas não estão à mostra, seus seios estão vestidos pela parte de cima de um biquíni bastante amplo. Seu cabelo está preso em um rabo de cavalo comportado, REAd - Edição 68, Volume 17, Nº 1, jan/abr 2011 - p. 01-25 
enquanto o cabelo do homem é menos conservador. Não há um produto em destaque e os efeitos do consumo de suplementos alimentares são tratados de forma genérica em texto: "A Neonutri tem uma completa linha de suplementos alimentares que irão ajudar você a emagrecer e definir músculos com saúde!"

A função de mostração é composta por um universo diferente daquele visto nas demais categorias. $\mathrm{O}$ universo não é centrado no corpo feminino ou no produto e se mostra mais centrado em um evento: a chegada do verão. Folhas de um coqueiro e o mar estão à vista do receptor e compõem o cenário.

A interação com o receptor é construída a partir da identificação de uma situação divertida de férias de verão. É fácil para o receptor construir uma relação com a propaganda em função do evento. A função de sedução está localizada na diversão que é sugerida na imagem e através do texto - "O verão está chegando, fique bem na foto." Ainda assim, o corpo feminino é apresentado como um corpo comportado e dominado pelo homem.

Figura 04 - Corpo Feminino Comportado

\begin{tabular}{|l|l|}
\hline Função de Mostração & Centrado no Evento \\
\hline Função de Interação & Baseada na situação - casal que passa o verão junto. \\
\hline Função de Sedução & Subordinação - mulher comportada e feliz \\
\hline
\end{tabular}

Fonte: elaborado pelos autores

\section{CONSIDERAÇÕES FINAIS}

O presente artigo buscou oferecer uma análise a respeito dos significados culturais atribuídos ao corpo feminino através de propagandas de suplementos alimentares. Através da análise do discurso publicitário de nove peças publicitárias de suplementos alimentares, foi possível traçar uma interessante perspectiva a respeito dos significados associados ao corpo feminino que emanam do mundo culturalmente constituído, conforme proposto por McCracken (2003).

A preocupação dos pesquisadores não residiu na compreensão do consumo de suplementos alimentares, mas sim nas formas de transferência do significado do corpo feminino que estão presentes em peças de propaganda destes produtos. Assim, as quatro categorias de construídas - Corpo como Fonte de Poder; Corpo como Local de Ação do Produto; Corpo como Confirmação do Produto; Corpo Feminino Comportado - mostraram-se capazes de oferecer uma base para discussão da transferência do significado do corpo feminino do mundo culturalmente constituído para o indivíduo.

REAd - Edição 68, Volume 17, No 1, jan/abr 2011 - p. 01-25 
UM ESTUDO SOBRE OS SIGNIFICADOS DE CONSUMO ASSOCIADOS AO 20

CORPO FEMININO EM PEÇAS PUBLICITÁRIAS DE SUPLEMENTOS

ALIMENTARES

Na primeira categoria percebe-se que o corpo feminino deixa de ser visto como frágil e passa a ser oferecido à mulher a possibilidade que seu corpo possa lhe oferecer um poder. Esse poder parece estar em grande parte associado ao valor do seu corpo em um "mercado" do corpo. Assim, o valor do corpo é definido a partir de um processo de aproximação da esfera pessoal do indivíduo a uma dimensão coletiva, onde o indivíduos e seus corpos são comparados e, portanto, valorizados e desvalorizados ("mercadizados"). Ao poder apresentar um corpo valorizado nessa estrutura de mercado, a mulher pode perceber respostas afetivas positivas (orgulho) e elevar sua auto-estima, como se a "mercadização" de seu corpo pudesse lhe promover uma espécie de emancipação.

A segunda categoria aponta de forma objetiva os efeitos dos produtos sobre partes dos corpos femininos e oferece às mulheres a oportunidade de darem rostos a corpos perfeitos. A separação do corpo em partes define uma perspectiva industrial ao corpo e a possibilidade de construção do indivíduo em peças. A aproximação da idéia de "mercadização" do corpo não é caracterizada aqui pelo valor do corpo, como na primeira categoria, mas pela possibilidade de engenharia do produto corpo. A fragmentação do corpo serve como reforço da ação do produto (consumo para o corpo) e, ao mesmo tempo, como estabelecimento de espaços corporais de consumo (consumo do corpo): a barriga lisa, as pernas sensuais e feminilidade dos seios.

A terceira categoria reforça os aspectos de ação do produto (consumo para o corpo) e de espaço de manifestação dos efeitos dos produtos (consumo do corpo) tratados na segunda categoria, mas acrescenta um outro componente: a proposição de um estilo de vida centrado no corpo associado à modernidade e praticidade e ao sentimento de prazer. Possuir um corpo magro e socialmente valorizado passa não só a ser possível como fácil e prazeroso. Dessa forma, qualquer indivíduo passa a poder participar desse "mercado" do corpo, o que reforça a o processo de naturalização desse mercado.

A peça publicitária classificada na quarta categoria altera as formas de apresentação do corpo feminino presentes nas demais peças. O componente masculino e dominador aparece para propor uma intervenção ao processo de "mercadização" do corpo a partir da valorização da subserviência. O processo de determinação do valor do corpo feminino passa a ser definido com base em parâmetros masculinos.

REAd - Edição 68, Volume 17, No 1, jan/abr 2011 - p. 01-25 
Figura 05 - Categorias observadas nas Peças Publicitárias

\begin{tabular}{|c|c|c|c|c|}
\hline & $\begin{array}{c}\text { Corpo como } \\
\text { Fonte de Poder }\end{array}$ & $\begin{array}{c}\text { Corpo como } \\
\text { Local de Ação do } \\
\text { Produto }\end{array}$ & $\begin{array}{c}\text { Corpo como } \\
\text { Confirmação do } \\
\text { Produto }\end{array}$ & $\begin{array}{c}\text { Corpo Feminino } \\
\text { Comportado }\end{array}$ \\
\hline $\begin{array}{l}\text { Função de } \\
\text { Mostração }\end{array}$ & $\begin{array}{l}\text { Corpo Poderoso - } \\
\text { corpo é um objeto } \\
\text { que gera valor } \\
\text { para a mulher }\end{array}$ & $\begin{array}{l}\text { Ação do Produto - } \\
\text { corpo é um local } \\
\text { onde produto } \\
\text { exprime seu valor }\end{array}$ & $\begin{array}{l}\text { Aval do corpo - } \\
\text { confirmação da } \\
\text { ação do produto } \\
\text { pela mulher }\end{array}$ & $\begin{array}{l}\text { Centrado no } \\
\text { Evento }\end{array}$ \\
\hline $\begin{array}{l}\text { Função de } \\
\text { Interação }\end{array}$ & $\begin{array}{l}\text { Status do Corpo - } \\
\text { corpo perfeito } \\
\text { construído } \\
\text { socialmente }\end{array}$ & $\begin{array}{c}\text { Baseada em } \\
\text { Técnica }\end{array}$ & $\begin{array}{c}\text { Autoridade } \\
\text { gestual, Olhar } \\
\text { imperativo }\end{array}$ & $\begin{array}{c}\text { Baseada na } \\
\text { situação }\end{array}$ \\
\hline $\begin{array}{l}\text { Função de } \\
\text { Sedução }\end{array}$ & $\begin{array}{c}\text { Auto-Estima } \\
\text { Elevada }\end{array}$ & Sensualidade & $\begin{array}{c}\text { Prazer e } \\
\text { Praticidade }\end{array}$ & Subordinação \\
\hline
\end{tabular}

Fonte: elaborado pelos autores

A contribuição desse artigo não está baseada apenas na percepção de que podem ser definidas quatro formas diferentes de comunicação de produtos para as mulheres. Afinal, não é surpreendente que produtores de suplementos alimentares observem segmentos diferentes de consumidoras e, como ofertantes de qualquer outra categoria de produto, definam estratégias diferenciadas de comunicação. O que esse artigo coloca também em questão é a aproximação do mercado a dimensões onde originalmente não é natural. A transformação do indivíduo e de seu corpo em produtos que podem ser transacionados em mercados não está propriamente colocada dentro das teorias de consumo. Os diversos componentes envolvidos nesse processo (sexualidade, dominação, estética) deixam claro que a naturalização do mercado em outras dimensões, tais como o corpo, traz aos estudos de marketing e consumo a necessidade de se explorar novas formas de teorização.

Ficou claro que o corpo é tratado como um objeto que pode ser consumido e apresentado aos olhos dos outros como representação de um self e não mais como o indivíduo. O corpo como objeto se torna alvo de investimentos, assim como um imóvel que sofre reforma para aumentar seu valor no mercado. A "mercadização" do corpo percebida corrobora a visão proposta por Malysse (2007). Ao constituir um mercado, o corpo passa a ser cotado em valor, se torna um capital, como proposto por Goldenberg (2007). Uma vez que o corpo se torna capital, cercado de investimentos (tempo, dinheiro, entre outros), a sua manifestação "em forma” apresenta-se como sucesso pessoal (GOLDENBERG, 2007).

REAd - Edição 68, Volume 17, No 1, jan/abr 2011 - p. 01-25 
Além dos achados da pesquisa, parecem interessantes considerações acerca dos procedimentos metodológicos. Desde a formulação do problema de pesquisa, estava claro para os pesquisadores que ainda não havia sido utilizado na área de administração uma metodologia que permitisse aos pesquisadores se aproximarem das peças publicitárias de forma adequada. Foi necessário recorrer a outros campos do conhecimento e a primeira procura na área de comunicação se revelou muito produtiva ao expor o método de análise do discurso publicitário.

A utilização do método de análise do discurso publicitário pode ser considerada uma contribuição relevante desse artigo. Poucos métodos são capazes contemplar a análise de texto e imagens simultaneamente de forma tão bem sucedida. Em que pese a necessidade de capacidade e treinamento dos pesquisadores em métodos de análise de orientação interpretativa, o resultado da utilização desse método foi bem sucedida e foi capaz de trazer contribuições interessantes para os estudos de consumo.

Pesquisas acadêmicas sobre propaganda são mais freqüentes na área de comunicação social, onde são encontrados estudos que tratam da imagem (PETERMANN, 2006; SOUZA e SANTARELLI, 2008) e do discurso (DIEGUEZ, 2006, TAVARES, 2006) na publicidade. A compreensão das propagandas pode ser muito interessante, pois, conforme McCracken (2003), a publicidade atua como um mecanismo de transferência de significados do mundo culturalmente constituído aos indivíduos, o que pode auxiliar pesquisadores da área de marketing a entenderem melhor o comportamento do consumidor e outros temas ligados à área de marketing.

Ao analisar os significados dos corpos femininos transferidos em propagandas de suplementos alimentares os pesquisadores buscaram compreender como o movimento do significado cultural e de consumo pode ajudar a esclarecer parte da complexidade do consumo atual em relação ao corpo e sua participação na sociedade de consumo. Mesmo em se tratando de peças promocionais criadas para linhas de produtos de suplementação alimentar, percebeuse, ao fim, que é o corpo que está sendo comprado/consumido. Os significados transferidos se mostraram dependentes do significado do corpo. Os pesquisadores esperam que os resultados desta pesquisa sirvam como incentivo para que mais pesquisadores se dediquem a construção de compreensões a respeito dos significados de consumo e a respeito da ampliação do processo de "mercadização" a outras dimensões da vida humana.

REAd - Edição 68, Volume 17, Nº 1, jan/abr 2011 - p. 01-25 


\section{REFERÊNCIAS}

ACEVEDO, C. R.; NOHARA, J. J.; ARRUDA A L.; TAMASHIRO H. R. S.; BRASHEAR, T. How women are depicted in ads? A content analysis study with Brazilian advertisements. International Business \& Economics Research Journal, v.5, n.10, p.59-72, 2006.

ALMEIDA, V. M. C.; ROCHA, A. Efeito pátina: a inscrição de signos conotativos da passagem do tempo nos bens de consumo. Revista Comunicação, Mídia e Consumo, v.5, n.13, p.97-120, 2008.

BARBOSA, L.; CAMPBELL, C. Cultura, Consumo e Identidade. Rio de Janeiro: Editora FGV, 2007.

BERGER, M. Mídia e espetáculo no culto ao corpo: o corpo como miragem. SIANAIS. Revista Eletrônica de Ciências Sociais. v.1, n.2, p.121-160, 2007.

CARVALHO, C. M. A.; ORSANO, E. F. Perfil dos consumidores de suplementos alimentares praticantes de musculação em academias de Teresina. In: III Encontro de Pesquisa em Educação Física e Áreas Afins, 3, 2006, Teresina. Anais... Teresina: UFPI, 2006

CARVAlHO, N. Publicidade - A Linguagem da Sedução. São Paulo: Ática, 1996.

CASTRO, A. L. Culto ao corpo: identidades e estilos de vida. IN: VIII Congresso Luso-AfroBrasileiro de Ciências Sociais, 8, 2004, Coimbra. Anais... Coimbra: CLABCS, 2004

CUNHA, M. J. O corpo, o consumo e o investimento corporal: as dietas e o exercício. In: VI Congresso Português de Sociologia, 6, 2008, Lisboa. Anais... Lisboa: CPS, 2008.

DOUGLAS, M.; ISHERWOOD, B. O Mundo dos Bens: Para uma Antropologia do Consumo. Rio de Janeiro: Editora UFRJ, 2009.

DIEGUEZ, G. K. O discurso publicitário: desvendando a sedução. Revista Comum, v. 2, n.27, p.86108, 2006.

GARRINI, S. P. F. Do corpo desmedido ao corpo ultramedido. Reflexões sobre o corpo feminino e suas significações da mídia impressa. IN: V Congresso Nacional de História da Mídia, 5, 2007, São Paulo. Anais... São Paulo: ANHM, 2007.

GOLDEnBerg, M. O Corpo Como Capital: Estudos Sobre Gênero, Sexualidade e Moda na Cultura Brasileira. 2 ed. Rio de Janeiro: Record, 2007.

GOLDENBERG, M.; RAMOS, M. S. A civilização das formas: O corpo como valor. In: M. GOLDENBERG (org.) Nu e vestido. Dez antropólogos revelam a cultura do corpo carioca. 2. ed. Rio de Janeiro: Record, 2007.

HIRSCHBRUCH, M. D.; FISBERG, M.; MOCHIZUKI, L. Consumo de suplementos por jovens frequientadores de academia de ginástica em São Paulo. Revista Brasileira de Medicina do Esporte, v.14, n.6, p.142-163, 2008.

HOFF, T. M. C. Imaginado na publicidade. Caderno de Pesquisa ESPM, v.1, n.1, p.23-39, 2005.

LIPOVESTKY, G. A Terceira Mulher. São Paulo: Companhia das Letras, 2000.

MEAMBER, L. A.; VENKATESH, A. The flesh is made symbol: an interpretive account of contemporary bodily performance art. Advances in Consumer Research, v.26, p.190-194, 1999.

MCCRACKEN, G. Cultura e Consumo: Novas Abordagens ao Caráter Simbólico dos Bens e das Atividades de Consumo. Rio de Janeiro: Mauad, 2003.

MALYSSE, S. Em busca dos (H)alteres-ego: Olhares franceses nos bastidores da corpolatria carioca. In: In M. Goldenberg (org.) Nu e vestido. Dez antropólogos revelam a cultura do corpo carioca. 2. ed. Rio de Janeiro: Record, 2007.

NISHIDA, N. F. A imagem da mulher na publicidade: cenário das representações da ética de responsabilidade. UNIrevista, v.1, n.3, p.86-108, 2006.

PATTERSON, M.; ELLIOT, R. Harsh Beauty: the alternative aesthetic of tattooed women. European Advances in Consumer Research, v.6, p.23-28, 2003.

REAd - Edição 68, Volume 17, Nº 1, jan/abr 2011 - p. 01-25 
PETERMANN, J. Imagens na publicidade: significações e persuasão. UNIrevista, v.1. n.3, p.1-8, 2006.

PINTO, M. J. (2002). Comunicação e Discurso. 2. ed. São Paulo: Hacker Editores.

PORTARIA N. 29 DE 13 DE JANEIRO DE 1998. Dispõe sobre alimentos para fins especiais. Diário Oficial da União. Brasília, DF: ANVISA, 1998.

PORTARIA N. 222 DE 24 DE MARÇO DE 1998. Dispõe sobre alimentos para atletas. Diário Oficial da União. Brasília, DF: ANVISA, 1998.

SAUERBRONN, J. F. R.; AYROSA, E. A. T.; BARROS, D. F. (2009). Bases Sociais das Emoções do Consumidor: Uma Abordagem Complementar sobre Emoções e Consumo. Cadernos EBAPE.BR, v. 7, p.1-15, 2009.

SIQUEIRA, D. C. O.; FARIA, A. A. Corpo, saúde e beleza: representações sociais nas revistas femininas. Revista Comunicação, Mídia e Consumo, v.3, n.9, p.171-188, 2007.

SOUZA, S. M. R.; SANTARELLI, C. P. G. Contribuições para uma história da análise da imagem no anúncio publicitário. Intercom - Revista Brasileira de Ciências da Comunicação, v.31, n.1, p.133156, 2008.

TAVARES, F. Publicidade e discurso: a perspectiva discursiva. Revista Comum, v.11, n.26, p.117$144,2006$.

\begin{abstract}
RESUMO
O presente artigo buscou analisar os significados atribuídos aos corpos femininos e transferidos através de propagandas de suplementos alimentares. O corpo se transformou em objeto de pesquisa de pesquisadores interessados em explorar a construção de significados de consumo de diversas áreas. Sua expressão como mercadoria já foi apontada por pesquisadores como Malysse (2007) que propôs a objetificação do corpo e Goldenberg (2007) que construiu o conceito de corpo como capital. Segundo MacCracken (2003), a publicidade atua na transferência de significados, desde o mundo culturalmente constituído até os indivíduos. As nove peças publicitárias coletadas foram analisadas com base no método de análise do discurso publicitário proposto por Pinto (2002). As funções de mostração (construção do universo do discurso), de interação (estabelecimento de vínculos socioculturais) e de sedução (distribuição de afetos positivos e negativos) serviram como direção para que os pesquisadores buscassem compreender as formas de transferência de significado do corpo feminino através das peças publicitárias de suplementos alimentares. Alguns componentes do discurso publicitário foram comuns a todas as peças coletadas e evidenciaram o corpo como um objeto que pode ser modificado, ter suas medidas alteradas a partir do que é transmitido como desejável (um corpo sem gordura, magro e firme). Entretanto, puderam ser diferenciadas quatro categorias de discurso de transferência de significado do corpo. A primeira categoria de peças publicitárias coloca o corpo como objeto de poder e o supervaloriza como objeto. Nessa categoria, a interação com os indivíduos é baseada no status que o corpo pode oferecer ao sujeito e as emoções envolvidas tratam de elevar a auto-estima do indivíduo. A segunda categoria congrega peças publicitárias que apresentam o corpo como local da ação do produto. A interação, nesse caso, é baseada em técnica e as emoções envolvidas destacam a sensualidade e a feminilidade. As peças que compõem a terceira categoria tratam o corpo como confirmador da ação do produto. A interação é baseada em gestual reproduzido em imagens e as emoções estão associadas a prazer e praticidade. A quarta categoria apresentou significado diferente para o corpo feminino, tratando-o como objeto subordinado ao evento, comportado e feliz. Ao fim, ficou claro o tratamento do corpo como objeto que pode ser modificado, alterado, adequado de acordo com a intenção de seu proprietário, o que ajuda a explicar como o significado do corpo é construído socialmente e transferido do mundo culturalmente constituído até o espaço de consumo dos indivíduos.
\end{abstract}

Palavras-Chave: significados de consumo; discurso publicitário; cultura e consumo; corpo feminino; propaganda; marketing.

\title{
A STUDY ON THE MEANINGS OF CONSUMPTION ASSOCIATED TO THE FEMALE BODY ON DIETARY SUPPLEMENTS'ADS
}

\section{ABSTRACT}

This paper aims to analyze the meanings that are attributed to the female body and are transferred through dietary supplements' advertisements. The body became a research theme for researchers interested in exploring the construction of meanings of consumption in many areas. Its expression as a commodity has already been pointed out by researchers as Malysse (2007) who proposed the objectification of the body and Goldenberg

REAd - Edição 68, Volume 17, No 1, jan/abr 2011 - p. 01-25 
(2007) who built the concept of the body as a capital. According to MacCracken (2003), advertising works in the transfer of meaning from the culturally constituted world to the individuals. Nine ads were collected and analyzed through the advertising discourse analysis proposed by Pinto (2002). The functions of showing (mostração -the construction of the universe of discourse), interaction (interação - social and cultural linkages set) and seduction (sedução - distribution of positive and negative affects) were used as direction for researchers to seek ways to understand the meaning transfer of the female body through the ads. Some components of the advertising discourse were common to all materials collected and showed the body as an object that can be modified to what is transmitted as desirable (without a body fat, lean and firm). However, it could be distinguished four discourse categories of body meanings transferring. The first category shows the body as an object of power that is overvalued as an object. In this category, the interaction with individuals is based on the status provided by the body and deal with the emotions involved raise the self-esteem of the individual. The second category gathers advertisements that feature the body as site of action of the product. The interaction in this case is based on technique and the emotions involved emphasize sensuality and femininity. The pieces comprised in the third category treat the body as a confirmer of the product's action. The gesture-based interaction is reproduced in images and emotions associated with pleasure and practicality. The fourth category deals with different meanings for the female body, treating it as an object subordinate to the event, well behaved and happy. In the end it became clear the treatment of the body is treated as an object that can be modified, altered, turned appropriate according to the intention of its owner, which helps explain how the body meanings are socially constructed and transferred from the culturally constituted world to the space consumption of individuals.

Keywords: consumption meanings; advertisement discourse; culture and consumption; female body; advertisement; marketing.

\section{ANEXO - PEÇAS PUBLICITÁRIAS UTILIZADAS NA PESQUISA}
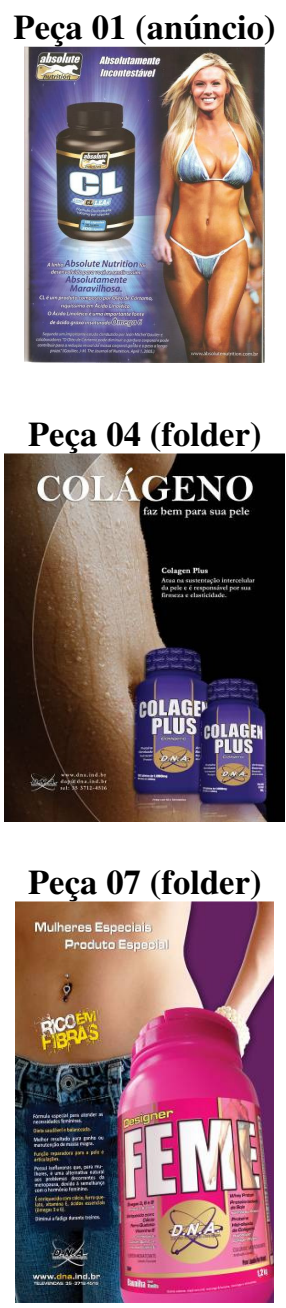
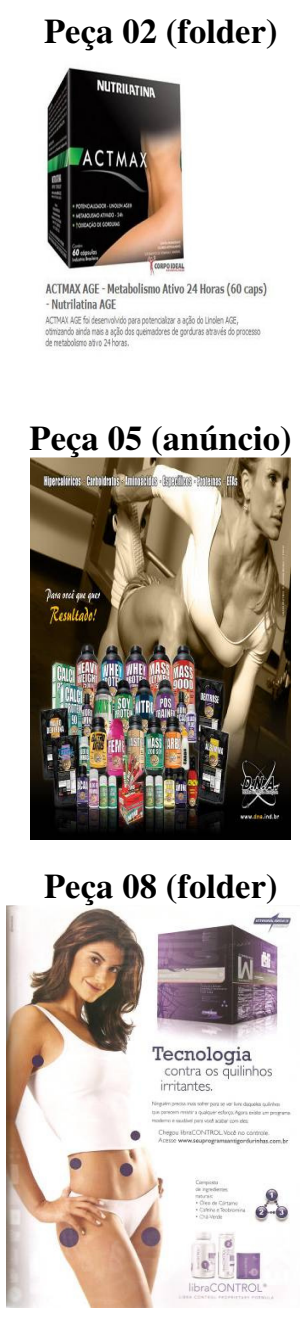
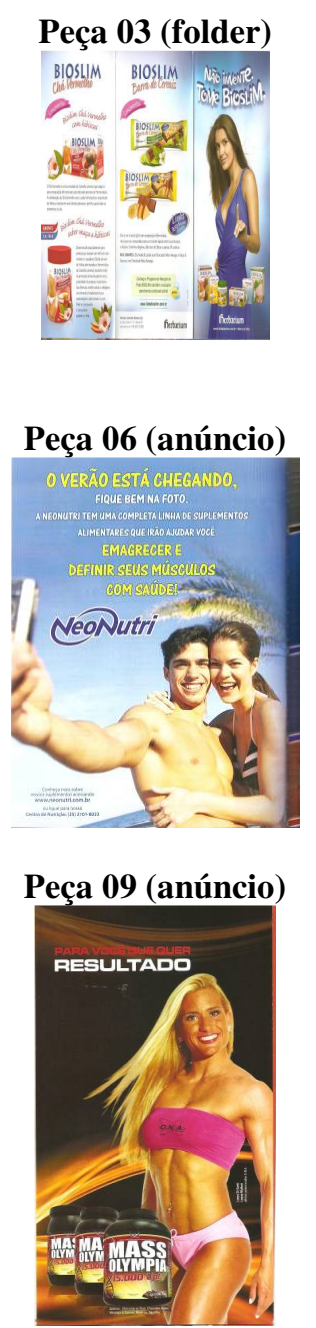